\title{
Values Education and Physical Education in Turkey
}

\author{
İlyas Görgüt ${ }^{1}$ \\ ${ }^{1}$ Dumlupınar University, School of Physical Education and Sport, Kütahya, Turkey \\ Correspondence: İlyas Görgüt, Dumlupınar University, School of Physical Education and Sport, Kütahya, Turkey. \\ E-mail: ilyasgorgut@hotmail.com
}

Received: September 25, 2017

Accepted: November 6, 2017

Online Published: February 25, 2018

doi:10.5539/ies.v11n3p18

URL: https://doi.org/10.5539/ies.v11n3p18

\begin{abstract}
In the $21^{\text {st }}$ century, science and technology have led to so many negative situations as well as positive developments for humanity. These negativities also affect human beings in a very intense way and in a natural result of this, people affect other's livings negatively. The general belief that the decelerating the events, actions and moral corruptions which lead to missing the peace of communities and the abolition of this negative situation will be ensured only by the development of the values which the individual possesses. Also states are taking precautions and making plans for this issue. So, value education in many countries has recorded a rapid acceleration in recent years. In Turkey, there are also some sections which have theoretical course curriculum and some scientific activities about values. However, it is considered that development in value and value education concepts are not enough and the applied courses such as physical education and sports, which aim to improve the individual as a whole, do not take place as much as within the scope of value education. For this reason, it is aimed to establish a point of view in the light of the works done in the Turkish science literature and the activities carried out by the related stakeholders for value education. Research was prepared as a document analysis form. Resources related to the physical education and value education in Turkey were collected and general evaluations were made through the obtained data and finally some suggestions were made.
\end{abstract}

Keywords: Turkey, values, education, physical education

\section{Introduction}

Human beings are in a central position because of influencing every kind of development and being influenced by them. In particular, questioning and interpretation of an event which a person faced as good-bad or wrong-right and the action which they have taken as accepted or not accepted, take a lot of time. The purpose of eliminating this time-consuming and negative situation merged at the point of improvement of the individual. Because the concept of healthy individual and healthy society direct individual and community specially and basic policies of the countries generally. By means of these policies it is aimed to transfer the universal values to the individual and to improve the existing values in order to ensure well-being. Therefore, it confronts us the concepts of values and value education that occupied the agenda of the society for many years.

Physical education aims to educate children and young people with their learning experiences, to help them to engage in activities that are physically active, to provide information, motivation and struggle and to give them physical, moral, intellectual and social education (Edinburgh University, 2014). With being the subject of many science branches, physical education and sport is in forefront of the other branch in value education. It develops a person as a whole and to contribute to his/her development. Along with this hypothesis, the character education and development of values through physical education have become an area where works intensively studied and frequently discussed.

Considering the contribution of physical education and sport in value education, it is a major issue to be emphasized how this concept takes part in Ministry of National Education plans and programs and in the education curriculum of the countries which reflect the ideology or the long-term programs of the country. Because of determining the concepts how and in what proportions will be evaluated in curricula, especially in course content, it is thought that the country will provide great contributions to the values education of the individual development. Furthermore after Ministry of National Education, Ministry of Youth and Sports has a great responsibility in the development of new generations because of being an authority on the plans for youth and being a decision-making authority on sport policies. For this reason, it is necessary to know the activities and approach of Ministry of Youth 
and Sports to the issue. As a result, it is possible to find intensive studies to support the mental, psychological and physical development of the individual through physical education, sport or physical activity. However in Turkey, there are limited studies on the benefits and contributions of physical education and sport in acquiring or developing the values which have directly targeting the individual. For this reason, it is aimed to draw attention of scientists and related institutions to the physical education and value education by examining the studies carried out by the Ministry of National Education, the Ministry of Youth and Sports and Turkish science literature.

\subsection{Value}

While humans are reasoning and questioning their ideas in the face of events and emerging situations, philosophy branch explaining idea and universal issues for each field of science, is primarily benefited from. Other than existence and knowledge, value is also the third area where philosophy evaluates problems with a systematic, rational and critical point of view (Uyanık, 2007, cited from Çakıroğlu, 2013, p. 10).

Value is defined as any kind of feelings, thoughts, behaviors, rules, or assets accepted in a society, in a belief, in an ideology or accepted, adopted and kept alive by people (Çelikkaya, 1996; Erdem, 2003, cited from Gül, 2013). So it is the criteria to determine what is right and what is wrong, what is good and what is bad. (Şişman, 2002, cited from Aslan, 2011). Value is an abstract criterion that helping to determine the importance of something and a response, property or a belief which is shown whether something is requested or not (Eser, 2012; Turkish Language Society, 2017). Trommsdorff and Chen (2012) describe value as state of mind, changeable, transcendental, admirable, persistent purpose and principles guiding human life (Gorgut, 2015). Values are expressed as creating mental learning of both front and background that shaping the future of someone, making individual's life meaningful and liberating. It is often stated that there are situations, not clearly perceived by others (Gül, 2013).

According to Özensel (2007) value is an abstract generalized behavioral principle in which members of a group exhibit a basic standard in judging their actions and purposes that concern them and exhibit strong emotional commitment. Aydin (2010) describes it as individual or socially recognized importance or superiority to any object or entity and Püsküllüoğlu (2003) describe as qualification that determines the significance of objects and events in terms of society, class or people (Çakıroğlu, 2013). Hanssona (2010) emphasizes that each person has values in their core and value is an abstract concept like desire and pride and therefore people adopt the values without being aware of it (Ergün, 2013).

Values are important, superior in other words adopted, admired or valid things for human (Aslan, 2011). Value is a choice that affecting decisions, determines our point of life view, reflecting our beliefs and constitutes our principles (Aktepe \& Yel, 2009, cited from Bolat, 2011). It is a belief produced by the ability of thinking that makes human superior between living things (Eser, 2012). That is, what is considered to be the best, the right, the most beneficial and the most useful in society. These are features that people or groups have or are accepting and are valid across communities that have the characteristics of being good for everyone, not for personal desires or pleasures (Gül, 2013). Kluckhohn (1951) also questioned the value socially. According to him, value is the means used to reach things desired in a society. Similarly, from an inter-societal point of view, which is another aspect of society, it is a set of beliefs or intercultural priorities that are relevant to social situations, goals and events (Ergün, 2013).

Because of its critical role in shaping the personality, the concept of value has taken place in recent years as value education within educational programs in order to reach children at an early age and to contribute in the moral direction. Thornberg and Oguz (2013) refer value education as ethical activities in which teachers consider the moral effects and complicated nature of teaching on children, the values and moral that children learn or develop in school activities.

\subsection{Values Education}

Human beings are not an entity who lives only the present time like other creatures. On the contrary, it is an entity that perceives and evaluates the assets and events of the past, the present and the future with consciousness in a three-dimensional time. Because of these features, it is the only entity that has the power and the ability to set an aim and a goal for it, make plans for realizing them, can dominate the existence by surrounding past and the future. So the most important factor that plays a role in making plans for realizing the goals and targets of the people is the sense of value. Because it is the belief and love of the person who directs his actions and influences his will (Gül, 2013). The fact that it has such an important position draws attention to the education of these values. Among the first practices for values education are the activities which were launched by the United Nations Educational, Scientific and Cultural Organization in 1995 with the slogan "Sharing our values for a better world" and Brahma Kumaris's "Living Values Education Project" as part of 50th anniversary celebrations of organization. The project 
focuses on 12 universal values such as freedom, happiness, honesty, love, humility, peace, respect, responsibility, simplicity, tolerance and unity (Canadian Centers for Teaching Peace, 2017).

Aspin (2000) argues that value education is an introduction to morality and values, including the interrelationships of people, their ability to intelligently apply knowledge, values and rules about the domain of influence and having an established tendency to do so (cited from, Thornberg, 2008). Values include concepts such as education, values, religion and morality, personal and social education, health education, justice, reasoning, citizenship education and character (Bailey, 2013), in addition to moral and character education, there are many general topics such as civic education and environmental education and special topics such as community service practices (Moscardo \& Murphy, 2011).

Values are a way of changing behavior with real debates that open up what is right action, not by saying something, manipulating it or making it doctrine (Robb, 1998). Individuals are encouraged to develop their own ethical codes as well as to deal with other people's ethical codes. In addition, values education helps individuals to explore the meanings and examples of these experiences by thinking about their own experiences. It ensures formation of the self-esteem and respects ordinary values such as honesty, truth and justice (Can, 2008, cited from Özmen et al., 2012).

Values have recently become a new focus of attraction and energy source around the world with programs focused on service learning and learning that are designed to solve certain social problems such as sex, drugs, alcohol, flexibility education under different forms of moral, character, citizenship education or civic education (Lovat \& Clement, 2008). It is therefore seen as a life-long education which helps their social adaptation, responsibility development and identification of things that they like or dislike (Arcus, 1980; Halstead, 1996, cited from Ergün, 2013). Lickona (1992) notes that education of values is historically shared among three institutions: family, religion and school and these three institutions work together to shape future generations through value transfer. Because beyond cognitive level, gaining values and attitudes in emotional and behavioral dimensions will enhance the quality of life in the school and students will feel happier and safer at school. Thus, while children grow up as good-natured citizens on the one hand, they will have the ability to learn the skills and knowledge they will use most effectively in everyday life (Okudan, 2010). In short, values education involves strengthening academic interests and achievements of young people and includes constructs and pedagogical skills for encouraging ethical and positive social trends within the school (Berkowitz, 2011). As a result, value education anticipates that individuals in the changing world will gain universal values with their own cultural and social judgments and be prepared for the difficulties that may arise (Gül, 2013).

\subsection{Values Education and Physical Education}

There is little interest about values in sport, especially in sport psychology, although human values are described as the dominant influence that governs the perceptions of reality that guide the actions of individuals in society (Lee et al., 2008). But in the mid-1800's, a tradition emerged which deeply influenced by sporting practices in the United Kingdom and the United States. It has begun to be seen as a tool by which students can be equipped with socialization, multiculturalism, social control and moral ideology through sports teams, especially in middle school. Training managers and leading physical educators therefore believe that sports will be effective in improving the values associated with effective citizenship in the modern society. In the direction of this belief, they tried to give the organization a sense of citizenship with sport and high institutional consciousness (Collins, 2014).

Benefits of moral development became one of the most controversial issues about works on citizenship through sports associations in 2004, in the Michigan State University youth sports research institute. In 2008, the European Union Working Group Sports and Health Workshop also emphasized the need to develop a strategy for sport promotion due to the impact of sport on community health, social values, gender equality and cultural values (EU Working Group, 2017).

It is thought that the concepts of respect and honesty, which constitute the character of the individual and considered as the golden rule in values, can be acquired through physical education or physical activity. While shaking, helping and listening to the teammate or rival in the sports environment seems to be a respect behavior, ridicule, shouting a cheerleader, cheating or trying to squash a defeated team is seen as a lack of respect. Integrity is understood in terms of coming to training on time, being ready for training, coaching to practice and showing the best possible performance in play/training environments (Doty, 2006).

The European Union's strategic objectives are a key to education and cultural values, a tool for integration, ways to combat intolerance, xenophobia and racism. Because of the committee of Economic and Social Affairs of the Council of Europe's recommendations that address sports to all groups without regard to gender, race, language or 
religion (European Economic and Social Committee, 2017). Gould and Carson (2008) view sport as a platform to maintain values that support the personal growth of young individuals and the development of competence (Koh et al., 2016). In addition, the Piagetian approach considers the development of the individual's psychological development and structure as one of the benefits of physical activity. In addition, a reflection of sports value trends is considered to be an instrument in which an individual symbolizes cultural values and a means of learning and experiencing core values in society (Bredemeier \& Shields, 1995).

People are learning to act with virtues such as overcoming obstacles, providing their own control, co-operating with their teammates, respect, honesty, fair play, compassion with participation in the sport (Jang, 2013). Values such as equality, participation, respect and justice in the active participation of students in society in their collective harmony and motivation are seen as the main sport values that strengthen their students (Unesco, 2015). According to Kleiber and Roberts (1981), it is possible to teach virtues such as cooperation, negotiation and learning to offer moral conflict solutions, justice, sportsmanship, team loyalty and teamwork, responsibility and obedience with friendships established through sports teams (Jang, 2013). However, although the athlete's character interprets his teamwork, loyalty, self-sacrifice, determination, work ethic and mental toughness as values; sports scientists, including sports philosophers and sports psychologists describe the sport character with honest, fair, responsible, respectful and compassionate (Rudd, 2005).

Arnold (1984) advocates that sports include freedom and equality, people enter the sports environment with their own desires and wishes by this way, they have developed responsibility and self-esteem through sports (cited from, Jang, 2013). In short, the sporting environment organized to develop character is important in acquiring sports experience, i.e. acquiring values. Such an environment includes all stakeholders, such as coaches, managers, families and participants. Appropriate and responsible behaviors and values developed in sport and physical education classes will be used in the family, in the community or out of the school and the community (Doty, 2006).

The contributions of physical education to building positive values cannot be denied. Teachers can use these lessons; cooperate with colleagues, encourage respectable individuals to live in harmony but we can also see moments when individualism, disrespect to their enemies and triumph over all circumstances cause to be far from creating the desired effect in sport participation and values to being assimilated (Freire \& Miranda, 2014). Nonetheless, the effectiveness of programs aimed at physical education and participation in sport are linked to self-esteem, educational attainment, psycho-social functioning, fair play, ethical reasoning and favorable behaviors among adolescents. In the conclusion report of the World Sports Managers Conference in Berlin in 2013, "physical education is reported to be the most effective tool for all children and young people to provide skills, attitude, value, knowledge and understanding for collective lifelong participation (Unesco, 2015). Vidoni and Ward (2009) found that through a fair play curriculum, students have had positive effects on their social skills as a result of some exercises in the course of teaching fair play. The interviewees stated that they cheered on their teammates and they were helping their falling peers. In addition, the researcher observed that teaching fair play made students more active at the point of participation (Koh et al., 2016).

Justice, team building, equality, discipline, participation, determination and respect are values that can be taught through sports, according to a report published by the Social and Humanitarian Affairs department of United Nations Educational, Scientific and Cultural Organization. Again, the Organization sees physical education curricula as bridges of value-based competences for learning and communication for the development of skills required by the $21^{\text {st }}$ century. Therefore, Values education through sport (VETS) indicates that students are increasingly responsible for their active learning, completing cognitive skills and increasing levels of concentration and participation. VETS programs are seen as possessing a flexible and strong curriculum potential because they can empower existing curricula and flow to different subjects such as physical education, citizenship education, spiritual education, nutrition, biology and arts. These programs help students to transform values outside of school by engaging with their own groups, making informed decisions, being sensitive and being respectful to others and environment. In addition, VETS programs support for the transition to adult independence which have self-confidence development, active and healthy lifestyle choices (Unesco, 2017).

According to the UK Education Department's physical education curriculum study, a high-level structured physical education and sports curriculum will support children's achievement in combat sports and other physical activities. It will reinforce the sense of physical trust, a way to be healthy and fit and develop the character to ensure internalization of values such as respect and justice (England Education Department, 2017). Child Development of Australia Melbourne Ministry of Education also emphasizes the importance of school sports in building a strong identity, culture and excellence. It emphasizes that traditional values such as respect, justice, responsibility, challenge will be achieved with the participation of the learners, the skills of sports students and the 
aspirations of students for interesting and rewarding lives. In addition, the Department is convinced that physical education has a strong bearing on attitudes towards participation in the physical and vital habits of students and it develops knowledge, understanding, skills and values to participate in healthy physical activity (Melbourne Department of Education, 2017). In 2009, speakers, presentations and workshops were held in Australia at the National Values Education Conference, which was attended by national and international speakers, stakeholders, curriculum leaders, teachers, principals and students and the importance of value education and the schools that pioneered and sustained Australian values education were discussed (National Values Education Conference, 2009). In 2016, attention was also drawn to humanitarian education in higher education in the International Conference on Human Values in Higher Education in India, the theme of education was undivided society and universal human rights, in which 170 participants from 13 countries participated (5th International Conference on Human Values in Higher Education, 2016 ).

\section{Method}

Document analysis method is used in this study. It is a form of qualitative research which aims to interpret document (Bowen, 2009). Document analysis method contains information about written and visual materials on cases which targeted for research (Yıldırım \& Şimşek, 2013). Resources related to the physical education and value education in Turkey were collected from web pages, regulations, curriculums, ministry publications, master's and doctoral thesis and protocols.

\section{Results}

In this section, expressions about the values education and physical education were examined and the results were shared under the titles of value education and physical education in Turkish science literature, value education and physical education in the ministry of national education and values education and physical education in the ministry of youth and sports.

\subsection{Value Education and Physical Education in Turkish Science Literature}

Values and values have been an intensely focused subject of scholars because of their educational sensitivity. Particularly, attitudes towards values and teaching of values are studied intensively. Regarding this situation, there are researchers in Turkey who are curious about the subject in different branches and conducting studies on this field, although it is not at the desired level.

Values and values education studies have been made in the Turkish science literature even though they are few in numbers compared to international researches when they are searched from databases of studies related to education. Despite the fact that the studies carried out in the field of physical education and sports take place widely in the international scientific area, the study titled "Education of values through physical education and sport", made by F. Kuter \& M. Kuter (2012) and Güllü (2016) are the studies emerge in Turkey and directly related to these concepts. In addition, in the thesis center of Higher Education Board, it is seen that only 264 masters and 57 doctoral studies has been published since 1993 in the scope of undergraduate education in Turkey. While studies are available in the fields of education and training, philosophy, music, psychology, radio-television, sociology, public relations, nursing, business, psychology, social services, German language, biology, geography, linguistics, religion and Turkish language and literature, only 4 studies were carried out 1 master thesis (Erkol, 2015) and $3 \mathrm{PhD}$ (Kanat, 2012; Görgüt, 2015; Doğan, 2015) under the heading of sport (Higher Education Board, 2017). Within the same date range, many international studies on values training are reached in the ProQuest thesis database (country-based approximate numbers Russia, 1.795, Spain, 2.281, England, 2.650, United States, 3.236 etc.). When these activities are filtered out under physical activity and physical education, it is observed that much more studies published in other countries than Turkey numerically (around 1800 studies).

\subsection{Value Education and Physical Education in the Ministry of National Education}

The Ministry of National Education is one of the institutions that work on values and teaching of values due to the undeniable importance of shaping future generations in Turkey. Statements related to values are included in the $2^{\text {nd }}$ and $11^{\text {th }}$ articles of the National Education Basic Law, which is the foundation law of the Ministry. It is aimed to educate citizens who adopt, protect and develop the national, moral, human, spiritual and cultural values of the Turkish nation with Article 2 in the general purpose section of the National Education Basic Law. In addition, Article 11 is the understanding that comes to the forefront; democracy education and the democracy consciousness that citizens should have, the sense of responsibility and respect for the spiritual values with the knowledge, understanding and behaviors belonging to the dormitory management (National Education Basic Law, 1973). However, there is no emphasis on direct value education in the law.

Although it is not enough, some steps have begun to be taken about values education that is starting to gain new 
meaning in Turkey. Firstly, the constructive teaching model has been adopted in all elementary schools in the country level since 2005-2006 education period by changing the related teaching methods and curriculums. Also, universal values began to be included in the curriculum such as to be fair among the disciplines, independence, peace, scientificness, hard work, solidarity, sensitivity, equality, tolerance, freedom, respect, love, hospitality, responsibility, cleanliness, honesty, patriotism, giving importance to being healthy (Görgüt, 2015).

It will be useful for us to follow the decisions of the Ministry of National Education on "National Education Policy" because it reflects the politics of the country, especially its values education or value teaching activities. In this regard, the decisions taken in the $9^{\text {th }}, 12^{\text {th }}, 18^{\text {th }}$ and $19^{\text {th }}$ National Education Council draw attention.

In the $9^{\text {th }}$ National Education Council, moral lesson took place as a separate lesson in the $9^{\text {th }}$ and $10^{\text {th }}$ grade curriculum of high school as "Moral Lesson" apart from "Religion knowledge Course" (Ministry of National Education, 1974). But it is seen that these courses combined as "Religion Culture and Moral Knowledge" which are separate after the decisions of the National Education Council (Ministry of National Education, 1988).

In the $18^{\text {th }}$ National Education Council which was prepared based on the vision of 2023, a separate section called "Sports, Art, Skills and Values Education" was opened and attention was drawn to values education. Also there;

- "Art Education for Humanity" and "Values and Education Project" should be prepared and put into practice.

- Priority should be given to approaches that will gain awareness in national and universal values together in teaching programs instead of value transfer in value education.

- Teachers should be educated in value education.

- Courses for value education should be put into all teacher training programs and in-service training programs.

- $\quad$ programs and materials should be developed by cooperating with civil society organizations for the teaching of values that can be shared by field teachers

- All courses and values education should be included in the school culture.

- Attention should be given to research and educational studies aimed at raising awareness of the relationship between media and values education.

- In addition to the academic achievement of the students, investment should also be made towards emotional, social and spiritual intelligence developments which are important in the formation of values.

- It has been decided that the "religious culture and moral knowledge" course, which plays an important role in the education of values, should be taught more effectively in all educational institutions with a pluralistic approach (Ministry of National Education, 2010). Again, in the $19^{\text {th }}$ National Education Council decisions were taken to include values education in preschool and junior high schools (Ministry of National Education, 2014).

Following the symposium on value education held in 2004, symposiums organized about the subject by the Ministry of National Education in 2010 and by Eskisehir University in 2011. In addition, the Ministry of Education has taken decisions that encourage values education activities in schools and the second symposium in 2012 by the Education Center, the topic was discussed in a platform where participants presented their ideas and practices from different countries ( $1^{\text {st }}$ International Values Education Congress, 2013).

After the decisions taken by the head council of education and morality since 2010, the "Values Education Directive" has been established and the related units and commissions have been defined and preparations have been made and started to be implemented at the initiative of Provincial Directorates. In addition, in 2013, the Board made decisions on Pre-School Education Values Training (Behavior Enhancement Centered Learning) (Head council of education and morality, 2017).

When it comes to the year 2017, draft curricula related to the courses have been established with the studies made within the scope of restructuring national education curriculum and these programs have been declared for the sections that want to contribute to the programs and to give their opinions. For physical education and sports, draft programs for primary school, middle and high school are presented. Within these programs, value education seems to be treated as a separate section.

It is stated that universal and social values are among the basic principles of the program in the section of the program of the game and physical activity lesson curriculum (primary school 1,2,3 and 4 classes) in which the precepts of value education are mentioned in the draft program (Ministry of National Education, 2017a).

The draft program of physical education and sports lesson curriculum (secondary school 5, 6, 7 and 8 classes) prepared for junior high schools includes universal and social values in the basic principles section, cultural 
accumulation and values about physical education and sports in the general principles section. In addition, fairness, friendship, aesthetics, equality, self-esteem, sharing, love, sensitivity (health, environment, culture, cultural heritage, historical heritage, individual differences), nature love, trust, cooperation, freedom, self-control, patience, responsibility, diligence, honesty, tolerance, self-esteem, respect, patriotism and helpfulness are the foregrounds in the general structure of the program emphasizing that values are one of the basic elements of curricula Ministry of National Education, 2017b).

In the syllabus of secondary education physical education curriculum, it is shown as a basic principle that students should be educated as conscious, well educated, responsible, respectful and confident individuals with human and moral values. In physical education class, it is very important for students to acquire competence, skills and attitudes such as motivating oneself and trusting oneself, exhibiting positive and constructive behaviors in individual and group sports activities, establishing empathy, respecting individual differences and acting in accordance with team spirit. For this reason, it is stated that acquiring, consolidating and applying these qualifications, skills and attitudes are necessary for all kind of activities related to physical education in and out of school; to contribute to the emotional, social and moral development of the students and to improve their sense of responsibility, will be beneficial (Ministry of National Education, 2017c).

Under the heading of "Cultural accumulation and values" and "Active and healthy life regular physical activity" within the three prepared draft programs aim to provide values such as traditional games, cultural accumulations such as national days and holidays, friendship, friendship, helpfulness, self-esteem and honesty intended.

\subsection{Values Education and Physical Education in the Ministry of Youth and Sports}

The Ministry of Youth and Sports is the top decision-maker in terms of youth and especially sports in Turkey. Due to this fact, the works of Youth and Sports Ministry on value education is important. So, if we have knowledge about the Ministry's work on the subject, it will lead us to see the importance given to the concept.

$1^{\text {st }}$ National Values Education Congress was organized by the support of the Ministry of Youth and Sports and within the scope of Konya Necmettin Erbakan University. It is stated that the Ministry will take place with a team of 20 people and nearly 200 academicians and experts will attend the congress. Within the scope of the Congress, 130 declarations will be presented in 4 different themes: "Adolescent and Value, Field Education, Society, Educational Sciences, Culture and Value". The main aim is to determine the needs of young people for their national, religious, material and spiritual values, to contribute to the quest for values and education, to discuss ideas in the field of national values and education and to examine examples of practice. The Values Education Module prepared by the General Directorate of Education, Culture and Research in line with the results of the Congress is stated to be developed and put into practice $\left(1^{\text {st }}\right.$ National Values Education Congress, 2013, Ministry of Youth and Sports, 2013). The second Congress was held in Kırıkkale University in 2015 and the congress was held with the participation of researchers and field specialist speakers ( $2^{\text {nd }}$ National Values Education Congress, 2015). It is also aimed to contribute to the physical and mental health and spiritual development of young people through projects that will be passed on through the cooperation protocol signed between the Ministry of Youth and Sports and the Presidency of Religious Affairs in 2015. It is stated that religion and values education will be provided to the young people who are in demand through the personnel to be appointed by the Presidency of Religious Affairs in their dormitories, in the camps and in the youth centers by providing motivation and spiritual guidance to the institutions affiliated to the Ministry of Youth and Sports. In addition, joint ministries and ministries affiliated to the Presidency will cooperate with each other to implement joint programs such as umrah programs through joint commissions. Under the protocol, Youth and Sports Minister Akif Çağatay Kılıç said that religious officials in the mosques were working in a sportive sense and that they were in need of materials and they were pleased with themselves. They would construct small sports complexes with football and basketball courts between the neighborhoods. As well as education Koran, calligraphy, illuminated manuscript education, training in different areas such as music, physical education and reading has been given. Director of Religious Affairs Dr. Mehmet Görmez states that the Ministry of Youth and Sports is as important as the protocols they signed with the Ministry of Justice, the Ministry of Family and Social Policies and the Ministry of Health and that they should pursue moral-oriented religiosity and aim at producing a productive rather than consuming values (Ministry of Youth and Sports, 2015).

The announcements reveal that the Ministry of Youth and Sports will contribute to the training of materials, fieldwork and courses to be made in Youth Centers and values, while the Presidency of Religious Affairs deals with the education of values within the scope of religiosity. However, the observation of the Ministry of Youth and Sports and Religious Affairs show us that two institution don't have work especially on physical education and value education. 


\section{Discussion and Conclusion}

It is designed to educate young people with curriculum based initiatives such as sports education, the personal and social responsibility teaching model, the socio-moral education curriculum for sports, for peace and the curriculum for cultural studies. In addition, John Dewey's experiential approach and the early work of the outbound motion, physical education and sports science-based adventure and outdoor education curriculum are seen as a means to support the personal and social development of students. The key value of such programs is to include alternative teaching methods, to emphasize both personal challenge and cooperative group work. The most important is to emphasize the relevance of life beyond school and to increase the connection with the curriculum (Bailey et al., 2009). However, when the situation of Turkish Ministry of Education on physical education and values is analyzed, it is seen that there is no direct application on values education for physical education. There is an implicit and theoretical understanding in the general curriculum, in a section under the title of values education which is created in the physical education draft curriculum in 2017 and it seems that there is no activities for practical gain. Chan (2004) notes that civil and moral education continues to be given in the form of hidden learning and implicit program contrary to the formal education and training curriculum in Chinese schools. In addition, teachers, families and training managers are trying to maintain these trainings through daily gatherings in the morning according to the teachers' personal beliefs or school philosophy or through weekly school meetings. However, Bain (1975) emphasizes that it is difficult to isolate and measure the effects of the hidden curriculum on students, even though teacher behavior and the classroom environment are assumed to have a comprehensive impact on the values, norms and behaviors of students. It also argues that although the goals and philosophy stated in the physical education program are so similar and cannot be distinguished from other programs but the content of the physical education program differs from the others. And it should be regarded primarily as part of the institution's open philosophy, not as an aspect of the hidden curriculum. Taking into consideration the studies carried out on the field, it is necessary for the children to be educated in the physical education curriculum. Studies in Turkey on values education and physical education are limited according to the world literature. In addition, The Ministry of Youth and Sports has supported some scientific activities on physical education and values, such as Religious Affairs. It is observed that the protocols on value education with institutions do not take place in any application about direct value education. They only support some scientific activities and signed protocols. According to science circles, there is strong evidence that participation in sports and physical activity increases children's self-esteem and that structured gaming and physical education and sports curricula contribute to improving self-esteem in children (Fox, 2000 and Gruber, 1985, Bailey et al., 2009). Therefore, in order to contribute to the social, moral and psychological development of future generations, the Turkish science circles, the Ministry of Youth and Sports as well as the stakeholders concerned should concentrate on physical education and value education and have a sense of understanding in their plans and programs.

\subsection{Suggestions}

- Values education should be organized to support the development of all aspects as a whole rather than the individual vaccination of religious, political, ethical subjects and etc.

- Increasing the studies in the literature in terms of value education and physical education, particularly depth examination of the context in postgraduate studies, will be encouraging at the point of attracting attention to values education.

- Scientific meetings, the congress, symposium etc. which will contribute to the field, should be supported, made more functional, steps towards implementation should be taken by planning with the results and actions should not to be put only on paper.

- At the undergraduate level, special theoretical and practical courses should be included only for value education.

- Besides the theoretical course, having practical courses with physical activities in value education in the Faculty of Sports Sciences or Physical Education and Sports colleges, will be beneficial.

- The Ministry of National Education is in a vital position in value education and curriculum of values education which integrated with physical education, will support the development of young generations.

- Values education should be emphasized at every level of national education schools. Particularly in pre-school education, play can contribute to both motor and value development.

- Restructuring of the Religious Culture and Moral Information course, organizing moral education or value education as a separate course is considered to provide positive contributions in achieving national education program goals. 
- Increasing the frequency of the education channels that guide the policy of the country and working on more specific topics rather than focusing on too many subjects (example: $20^{\text {th }}$ National Education Council "Values Education") can provide positive contributions.

- Sports or physical activity in value education should be seen as an important tool by the Ministry of Youth and Sports and its resources should be used effectively by developing its capacity in this direction.

\section{References}

$1^{\text {st }}$ National Values Education Congress. (2013). Retrieved from http://dek2013.konya.edu.tr/

$2^{\text {nd }} \quad$ National Values Education Congress. (2015). Retrieved from http://eydb.aile.gov.tr/data/55798c39369dc51284f4bad6/doc01696820150611131509.pdf

$5^{\text {th }}$ International Conference on Human Values in Higher Education. (2016). Retrieved from http://www.iitk.ac.in/hvhe/csummary.php

Aslan, M. (2011). İlköğretimde karakter ĕgitimi ve öğrencilere kazandırllması gereken değerler. Yüksek lisans tezi, Osmangazi Üniversitesi, Eğitim Bilimleri Enstitüsü, Eskişehir.

Bailey, R., Armour, K., Kirk, D., Jess, M., Pickup, I., Sandford, R., \& Education, B. P. (2009). The educational benefits claimed for physical education and school sport: an academic review. Research papers in education, 24(1), 1-27. https://doi.org/10.1080/02671520701809817

Bain, L. L. (1975). The hidden curriculum in physical education. Quest, 24(1), 92-101. https://doi.org/10.1080/00336297.1975.10519851

Berkowitz, M. W. (2011). What Works in Values Education. International Journal of Educational Research, 50, 153-158. https://doi.org/10.1016/j.ijer.2011.07.003

Bowen, G. A. (2009). Document analysis as a qualitative research method. Qualitative research journal, 9(2), 27-40. https://doi.org/10.3316/QRJ0902027

Çakıroğlu, A. E. (2013). Değerler Eğitiminde Korku Kültürünün Etkisi. Yüksek lisans Tezi, Abant İzzet Baysal Üniversitesi, Eğitim Bilimleri Enstitüsü, Bolu.

Canadian Centers for Teaching Peace. (2017). Livings Values. Retrieved from http://www.peace.ca/livingvalues.htm

Chan, C. H. (2004) Moral and civic education-the hidden curriculum in Macau, Journal of Moral Education, 33(4), 553-573. https://doi.org/10.1080/0305724042000315707

Collins, M. (2014). Sport and social exclusion. Routledge Publishing.

Doğan, İ. (2015). Beden eğitimi dersinin öğrenciye kazandırdl̆̆g değerlerin çeşitli değişkenler açısından incelenmesi. Doktora Tezi, Gazi Üniversitesi, Eğitim Bilimleri Enstitüsü, Ankara.

Edinburgh University. (2014). Physical Education. Retrieved from http://www.ed.ac.uk/polopoly_fs/1.44143!/fileManager/Physical-Education.pdf

England Education Department. (2017). National curriculum in England: physical education programmes of study. Retrieved from https://www.gov.uk/government/publications/national-curriculum-in-englandphysical-education-programmes-of-study/national-curriculum-in-england-physical-education-programmesof-study\#key-stage-3

Ergün, S. (2013). Ergenlere Verilen Değer Eğitiminin Öz Düzenleme Stratejileri Üzerindeki Etkisinin Sinanmast. Yüksek Lisans Tezi, Necmettin Erbakan Üniversitesi, Eğitim Bilimleri Enstitüsü, Konya.

Erkol, A. (2015). Bilecik İlinde bulunan 7-12. sinıf ögrencilerinin beden eğitimi dersine yönelik tutum ve davranışlarının değerler eğitimi açısından incelenmesi. Yüksek Lisans Tezi, Dumlupınar Üniversitesi, Sağlık Bilimleri Enstitüsü, Kütahya.

Eser, A. (2012). İlköğretim ikinci kademe ögrencilerinin insani değerler düzeyleri ile çevresel tutumları arasındaki ilişki. Yüksek Lisans Tezi, Yeditepe Üniversitesi, Sosyal Bilimler Enstitüsü, İstanbul.

EU Working Group. (2017). EU Physical Activity Guidelines. Retrieved from http://www.ua.gov.tr/docs/default-source/gen\%C3\%A7lik-program\%C4\%B1/eu-physical-activity-guideline s-2008-(ab-beden-e $\%$ C4\%9Fitimi-rehberi).pdf?sfvrsn=0

European Economic Social Committee (EESC). (2017). Retrieved from http://www.eesc.europa.eu/?i=portal.en.soc-opinions. 32712 
Görgüt, İ. (2015). Ortaokullarda görev yapan beden eğitimi ve diğer branş ögretmenlerinin ahlak, karakter ve değerler eğitimine ilişkin görüşlerinin incelenmesi. Doktora Tezi, Gazi Üniversitesi, Eğitim Bilimleri Enstitüsü, Ankara.

Gül, R. (2013). Bir Değer Eğitimi Olarak İlköğretim Döneminde Doğruluk Eğitimi. Yüksek Lisans Tezi, Hitit Üniversitesi, Sosyal Bilimler Enstitüsü, Çorum.

Gullu, M. (2016). Examining the values of students in the physical education and sport departments. Educational Research and Reviews, 11(19), 1812. https://doi.org/10.5897/ERR2016.2996

Head Council of Education And Morality. (2017). Council Decisions. Retrieved from http://tkb.meb.gov.tr/www/gecmisten-gunumuze-kurul-kararlari/icerik/18

Higher Education Board. (2017). Values Education. Retrieved from https://tez.yok.gov.tr/UlusalTezMerkezi/tezSorguSonucYeni.jsp

Kanat, S. (2012). Anadolu Güzel Sanatlar ve Spor Lisesi Resim Bölümü ile genel lise öğrencilerinin görsel sanatlar eğitimi alma durumlarına göre temel değer düzeylerinin incelenmesi. Doktora Tezi, Gazi Üniversitesi, Eğitim Bilimleri Enstitüsü, Ankara.

Kuter, F. Ö., \& Kuter, M. (2012). Beden eğitimi ve spor yoluyla değerler eğitimi. Eğitim ve İnsani Bilimler Dergisi, 3(6), 75-94.

Lee, M. J., Whitehead, J., Ntoumanis, N., \& Hatzigeorgiadis, A. (2008). Relationships among values, achievement orientations and attitudes in youth sport. Journal of Sport and Exercise Psychology, 30(5), 588-610. https://doi.org/10.1123/jsep.30.5.588

Lovat, T. J., \& Clement, N. D. (2008). The Pedagogical Imperative of Values Education. Journal of Beliefs \& Values, 29(3), 273-285. https://doi.org/10.1080/13617670802465821

Melbourne Department of Education. (2017). Improving school sport and physical education in your school. Retrieved from http://www.education.vic.gov.au/Documents/school/teachers/teachingresources/social/ physed/hpeimprovsport.pdf

Ministry of National Education. (1974). IX. National Education Council. Retrieved from http://ttkb.meb.gov.tr/meb_iys_dosyalar/2014_10/02113442_9_sura.pdf

Ministry of National Education. (1988). XII. National Education Council. Retrieved from http://ttkb.meb.gov.tr/meb_iys_dosyalar/2014_10/02113522_12_sura.pdf

Ministry of National Education. (2010). XVIII. National Education Council. Retrieved from http://ttkb.meb.gov.tr/meb_iys_dosyalar/2014_10/02113646_18_sura.pdf

Ministry of National Education. (2014). XIX. National Education Council. Retrieved from http://www.meb.gov.tr/19-mill-egitim-srasi-sona-erdi/haber/7594/tr

Ministry of National Education. (2017a). Curriculum of game and physical activity course (primary school 1, 2, 3 and $4^{\text {th }}$ grades) (draft program). Retrieved from http://mufredat.meb.gov.tr/Dosyalar/201711314051497yun\%20ve\%20Fiziki\%20Etkinlikler.pdf

Ministry of National Education. (2017b). Physical education and sports course curriculum (junior high school 5 , 6, 7 and $8^{\text {th }}$ classes) (draft program). Retrieved from http://mufredat.meb.gov.tr/Dosyalar/ 201711311048788-Beden\%20E\%C4\%9Fitimi.pdf

Ministry of National Education. (2017c). high school physical education course curriculum (draft program). Retrieved from http://mufredat.meb.gov.tr/Dosyalar/2017113114253247-Orta\%C3\%B6\%C4\%9Fretim\%20 Beden\%20E\%C4\%9Fitimi.pdf

Ministry of Youth and Sports. (2013). $1^{\text {st }}$ International Values Education Congress. Retrieved from http://www.gsb.gov.tr/HaberDetaylari/1/3460/1-ulusal-degerler-egitimi-kongresi-basliyor

Ministry of Youth and Sports. (2015). Values Training Protocol between Ministry of Youth and Sports and Presidency of Religious Affairs. Retrieved from http://www.gsb.gov.tr/HaberDetaylari/1/33369/genclik-vespor-bakanligi-ile-diyanet-isleri-baskanligi-degerler-egitimi-isbirligi-protokolu-imzalandi

Moscardo, G., \& Murphy, L. (2011). Toward Values Education in Tourism: The Challenge of Measuring the

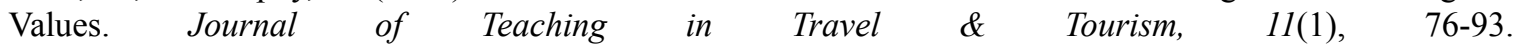
https://doi.org/10.1080/15313220.2011.548736

National Education Basic Law. (1973). Official newspaper. Release Date: 24.06.1973. Number: 14574/1739. 
National Values Education Conference. (2009). Values in Action: Shaping Positive Futures. Retrieved from http://wellbeingaustralia.com.au/wba/national_values_education_conference_2009/

Okudan, A. Y. (2010). Ĕgitim Yöneticilerinin Değerler Ĕgitiminin Önemi, Etkileri ve Uygulamaları Hakkındaki Görüşleri. Yüksek Lisans Tezi, Marmara Üniversitesi, Eğitim Bilimleri Enstitüsü, İstanbul.

Özmen, C., Er, H., \& Gürgil, F. (2012). İlköğretim Branş Öğretmenlerinin Değerler Eğitimine İlişkin Görüşleri Üzerine Bir Araştırma. Mustafa Kemal Üniversitesi Sosyal Bilimler Enstitüsü Dergisi, 9(17), 297-311.

Robb, B. (1998). What is Values Education- And So What? Scotland: Journal of Values Education, 1, 1-11.

Thornberg, R. (2008). The Lack of Professional Knowledge in Values Education. Teaching and Teacher Education, 24, 1791- 1798. https://doi.org/10.1016/j.tate.2008.04.004

Thornberg, R., \& Oguz, E. (2013). Teachers' views on values education: A qualitative study in Sweden and

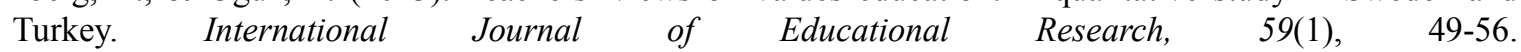
https://doi.org/10.1016/j.ijer.2013.03.005

Trommsdorff, G., \& Chen, X. (2012). Values, religion and culture in adolescent development. New York: Cambridge University Press. https://doi.org/10.1017/CBO9781139013659

Turkish Language Society. (2017). Value. Contemporary Turkish Dictionary. Retrieved from http://www.tdk.gov.tr/index.php?option=com_gts\&kelime=DE\%C4\%9EER

Unesco. (2015). Qualty physical education (qpe) guidelines for polıcy-makers. Retrieved from http://unesdoc.unesco.org/images/0023/002311/231101E.pdf

Unesco. (2017). Values education through sport innovative education for development. Retrieved from $\mathrm{http}: / /$ www.unesco.org/new/en/social-and-human-sciences/themes/physical-education-and-sport/values-edu cation-through-sport/

Yıldırım, A., \& Şimşek, H. (2013). Sosyal bilimlerde nitel araştırma yöntemleri (9. Genişletilmiş Baskı). Ankara: Seçkin Yayıncılık.

\section{Copyrights}

Copyright for this article is retained by the author(s), with first publication rights granted to the journal.

This is an open-access article distributed under the terms and conditions of the Creative Commons Attribution license (http://creativecommons.org/licenses/by/4.0/). 